\title{
NOTES
}

\section{MRS. GRUNDY AND WALT WHITMAN}

In the summer of 1865 there appeared in New York City an illustrated humor magazine called Mrs. Grundy. It was begun by several alumni of Vanity Fair: Henry L. Stephens, Edward F. Mullen, and C.D. Shanley. The most notable of their young contributors was Thomas Nast. Most of Mrs. Grundy's subject matter had to do with New York City: there were jokes and poems about garbage removal, the police, the city council, newspapers, and Wall Street. On one occasion a famous son of New York, Walt Whitman, provided the subject matter. The following sketch, "Whitmaniacal," appeared in the August 26 issue (p. 81); it has to this point escaped the notice of Whitman bibliographers.

A paragraph is "going the rounds" of the papers, to the effect that WALT WHITMAN, the "Yawper," having been dismissed from the Department of the Interior for the immorality of his "Leaves of Grass" has been given a place in the office of the Attorney-General.

We confess that this strikes us as incongruous and improbable, for several reasons.

Without entering into the question of the Shades of Morality (or Mowerality) displayed by WALT'S different Leaves of Grass-a delicate subject of investigation, belonging to the Agricultural Bureau, whose Verdant Science, or Scientific Verdancy, is notorious-we think the coup de grass is given to the above story by the following facts:-

First. - The Leaves of Grass produced by MR. WHITMAN could in no wise have affected the Moral, or Physical, Usefulness of the Department of the Interior, inasmuch as none of this Grass has ever come up, amid the many worthless crops which a confiding Public has constantly reaped from the generous confusion of this Department.

Secondly. - Though MR. WHITMAN'S Treatise on Grasses may have indirectly influenced his first appointment, neither he nor the Department of the Interior were so green as to make use of his "Leaves," further than was necessary to realize their mutual wish to live in clover together. The Department, therefore, would not send MR. W to grass, save in a playfully metaphorical manner, or for the purpose of making hay while the sun shone.

N.B. It is just possible, after all, that MR. WHITMAN'S immorality may have consisted in taking advantage of one of his "Leaves" to "cut a few capers" on his private "Hook," in which case he may very probably have been "turned over" to the legal tender mercies of the Attorney-General, for the purpose of having his "crop" per-(h)emp-torily cared for; since, although that Bureau is not much in the Agricultural line, a sort of HA(Y)MAN'S place may be found there, with SPEED, if necessary.

Finally, our strongest reason for disbelief in the statement concerning WALT lies in the fact that we-that-in short, that-we don't believe it! And so, no mower at present, from Yours,

TIMOTHY. 
It is difficult to determine whether the author had any serious purpose behind his sketch. Very possibly he was using the incident primarily as an opportunity to string together a long line of puns, mostly on the idea of making hay out of leaves of grass. The references to the Bureau of Agriculture, to hemp, clover, hay, the name "Timothy," the occupations of cutting, mowing, and turning over, all seem to indicate that the author was mainly interested in constructing puns. The real intent of the sketch seems to have been for the amusement of the tables at Pfaff's or some other place where poets and writers would gather. Possibly because Mrs. Grundy appealed to such a limited audience, the magazine lasted only twelve weeks.

Illinois State University

WiLliam R. LiNNEMAN

\section{WHITMAN AS THE NAZARENE: AN UNPUBLISHED DRAWING}

Among the holdings in the William D. Bayley Collection at Ohio Wesleyan University is a letter from Edward Carpenter to an unidentified "Benjamin," ecstatically describing Carpenter's first meeting with Walt Whitman on May 2, 1877. In 1961 Gay Wilson Allen printed the text of the letter, ${ }^{1}$ but not the remarkable appendage to it which appears on the back cover of this issue: a sketch Carpenter made to illustrate his description of Whitman's face:

The thing which strikes one about his face is the great interval between his eyes and eyebrows. That 'space in which the soul seems to move' is very large. The eyebrows very much arched so as to make the bridge of the nose very long-the nose itself straight \& well-proportioned. The mouth and chin are covered with a fall of white hair, but the forehead is clear and high. As to his eyes of course it is impossible to put them into words-the impression they produce on me is of an immense, immense, background: Yet it is very characteristic of them that the pupils are small \& distinct, the likeness to Christ is quite marked. I suppose it comes in the high eyebrows. I send you a sketch (!) which will give you an idea of the proportions of the face. Put into it the extravagant prophetic look of genius, intense perceptive power, and as much sentiment as you like, and you have something like. ${ }^{2}$

We may probably assume that Carpenter's exclamation point signifies good humored acknowledgment of his poor drawing skill, and his stated intent is only to suggest the "proportions of the face"-especially, it seems, the relationship of eyes to eyebrows that he found so Christ-like. Nevertheless the sketch, depicting a rather narrow face, scanty beard, and thin, straight hair, is interesting precisely because it does not look at all like Whitman. Allen's note on the matter goes straight to the point: "The sketch looks much more like a conventional image of Christ than any of the photographs of Whitman except possibly the frontispiece of the 1855 edition of Leaves of Grass. It plainly shows Carpenter's idealization of the poet." ${ }^{3}$ Indeed that idealization continues as the enthralled Englishman goes on to tell of walking with Whitman in the streets of Philadelphia, later on the day of their meeting. Walt-leaning on the younger man's arm, "for one foot is still semiparalysed"-is portrayed as the adored cynosure of the common folk: "The 'bus drivers, the ferryboat men, jacks of all 